\title{
School Support Services Model for Students With Disabilities in General Education Classrooms: Using Data From the Special Needs Education Longitudinal Study in Taiwan
}

\author{
Shu-Jou Sun, Tse-Yang Huang \\ National Hsinchu University of Education, Hsinchu city, Taiwan
}

\begin{abstract}
The purposes of this study were to establish a school support service model for students with disabilities in general classroom, and to explore the current status of school support services provided for students with disabilities in preschools, primary, and junior high schools. Therefore, this study used data from the Special Needs Education Longitudinal Study in Taiwan, collected in the 2007-2008 academic year. There were 2,924 students with disabilities selected in the study who were placed in general classrooms; 855 were in preschool, 1,079 were in primary school and 990 were in junior high school. The questionnaires in the database were answered by their teachers. The results of this study are listed, as follows: In terms of the school support service model for students with disabilities in the three stages of education, adjustment in teaching accounts for $1 \sim 15 \%$ of the explanatory power regarding the overall model, while support services account for $63 \sim 85 \%$, which peak in junior high schools. Secondly, itinerant teachers are found to be the most important human resource in preschools. For primary and junior high schools, parents and special education teachers are the more prevalent influences. The more common school support services are tuition refunds, itinerant services, adjustments in examinations, and scholarships.
\end{abstract}

Keywords: Special Needs Education Longitudinal Study, students with disabilities, school support services, general classroom teachers

\section{Introduction}

According to a report of U.S. Department of Education regarding the educational environments of students with disabilities aged 6 through 21 in 2010, students spending $80 \%$ or more of the day in a regular classroom account for $60.5 \%$ of the total, those spending $40 \sim 79 \%$ of the day in a regular classroom account for $20.1 \%$, while those spending less than $40 \%$ of the day in a regular classroom account for $14.2 \%$ (U.S. Department of Education, 2014). This means that as many as $94.8 \%$ of students with disabilities were educated in regular classroom, while enjoying various special education services. This leaves only $5.2 \%$ of students with disabilities educated in special schools, facilities, and homebound education services. However, these studies found that some regular classroom teachers in primary and secondary schools argued against the idea that all students with disabilities were suitable for regular education (Cook, 2001; Cook, 2004; Varma, 2007). Moreover, it was the opinion of some regular classroom teachers that most students with disabilities were incapable of mastering what they learned in a regular

Shu-Jou Sun, Ph.D., Associate Professor, National Hsinchu University of Education.

Tse-Yang Huang, Ph.D., Assistant Professor, National Hsinchu University of Education. 
classroom (Santoli, Sachs, Romey, \& McClurg, 2008). In addition, three major difficulties are posed regarding the implementation of inclusive education: the inadequate expertise in special education; lack of sufficient time; and shortage of in-school and out-of-school resources (Forlin, 1995; Vaughn \& Schumm, 1995). Thus, the support of peers in regular classes, cooperation among professional teams, extra human resources, administrative support, improved teachers expertise, etc., have been proved effective strategies for successful inclusive education (Alquraini \& Gut, 2012; Maheady, Mallette, \& Harper, 2006; Mastropieri, Scruggs, Graetz, Norland, Gardizi, \& McDuffie, 2005; O’Rourke \& Houghton, 2008; Santoli et al., 2008).

The so-called school support services refer to the necessary resources provided by the school administration, including special education teachers and relevant professionals to assist regular classroom teachers in the face of the special needs of students with disabilities, such as teaching methods and behavioral consultation, in order that regular classroom teachers can develop strategies to make adjustments to their teaching methods, environmental planning, and behavioral consultation, thus, helping students with disabilities better adapt to the school. The National Dissemination Center for Children with Disabilities (abbreviated as NICHCY) provides that the support services should include: assistive technology devices, assistive technology services, consulting services, rehabilitation counseling services, medical services, school health services, orientation and mobility services, psychological services, social work services, etc. (U.S. Department of Education, 1999). The National Longitudinal Transition Study-2 (abbreviated as NLTS2) divides the support services into the following categories: personal counseling services, therapeutic services, health-related services, career transition services, academic enhancement services, accessibility and mobility enhancement services, human resources services (U.S. Department of Education, 2004). Alquraini and Gut (2012) summed up the important support services for regular classroom teachers as the seven dimensions of: curriculum adaptations, assistive technology, collaboration among special education teachers and other professionals, administrative support, professional development programs of expertise, and parental support. Downing and Peckham-Hardin (2007) suggested that support services for regular classroom teachers should consist of the three dimensions of: curriculum adjustment, teamwork, and peer support. Blackorby et al. (2007) discussed school support for students with disabilities in regular classes from the two dimensions of adjustment and learning support. Adjustments are achieved by allowing more time of assessment, choosing an alternate assessment, making changes to the grading standards, slowing the speed of teaching, etc. Learning supports include human resources support, translators or interpreters, behavioral management plans, learning strategies, etc. In conclusion, school support services could be achieved through various dimensions, such as adjustments in curriculum and teaching, support from the school administration, behavioral management plans, teachers and other kinds of human resources support, assistive technology, peer support, parental support, and enhancement of teachers' expertise.

The above studies also found that: students with visual impairments tend to obtain more support from professional itinerant teachers and assistive technology services, those with emotional and behavior disorders tend to obtain more psychological counseling services, those with orthopedic impairments and multiple disabilities receive more physical therapy, and students with speech and language impairment, autism, and multiple disabilities were provided with more speech therapy (U.S. Department of Education, 2004). The reduction in the teacher-student ratio, a structured teaching environment, acceptance by peers, support from special education teachers, cooperation between teachers and parents, etc., were found to be effective in enhancing the learning outcomes of students with ADHD, autism, and Asperger syndrome in regular classes 
(Coffey \& Obringer, 2004; Jindal-Snape, Douglas, Topping, Kerr, \& Smith, 2005; Koenig, Bleiweiss, Brennan, Cohen, \& Siegel, 2009).

The Special Needs Education Longitudinal Study (abbreviated as SNELS) is a longitudinal database for students with disabilities, which was established to collect the data of individuals with disabilities, their families, and schools in the four stages of education, preschool, primary school, junior high school, and senior high school in a comprehensive and longitudinal manner, thus, facilitating investigations into the important issues for the education of individuals with disabilities. SNELS is mainly characterized by: (1) the inclusion of the fifteen-year-long longitudinal studies of students with disabilities regarding their education or exit from education; (2) longitudinal studies of students with disabilities spanning 3 5 years, thus, enabling comparisons and analysis of cross-year data; and (3) collection of information on the administrative implementation of special education services by the department of education at the county (municipal) level, thus, providing a full picture of the education of individuals with disabilities in Taiwan (Academia Sinica, 2014).

Therefore, this study was to establish a school support service model for students with disabilities in regular classroom by using the data retrieved from the SNELS, in addition to probing into school support services for students with disabilities currently in regular classroom.

\section{Methods}

\section{Research Model}

On the basis of relevant literature, a theoretical model of school support services for students with disabilities in regular classroom is established in this study. As seen in Figure 1, the latent independent variables of this model are "teacher expertise" and "human resources". "Teacher expertise" is represented by the two observed variables of participation in special education workshops and the benefits of these workshops. "Human resources" is represented by the four observed variables of extra human resources, help from itinerant teachers, cooperation with special education teachers, and the assistance of relevant professionals. The latent dependent variables include "Teaching adjustment" and "School support services". "Teaching adjustment" is constituted by the two observed variables of the means and adequacy of teaching adjustments. "School support services" are represented by the four observed variables of assistance from the school, support services for students, support services for parents, and the adequacy of the services. This model hypothesizes that the two latent independent variables of teacher expertise and human resources can directly influence on the provision of teaching adjustments and school support services, while indirectly influence on the latter via the mediators.

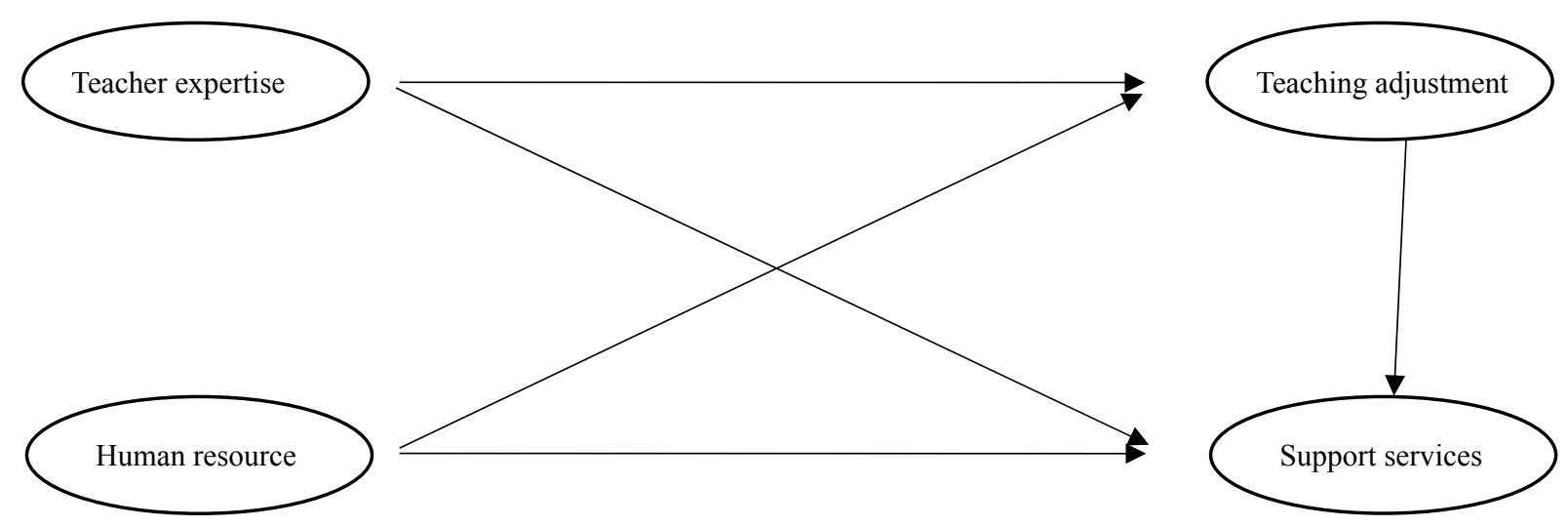

Figure 1. School support services model for students with disabilities. 


\section{Participants}

There were 2,924 students with disabilities who were placed in general education classrooms selected from the Special Needs Education Longitudinal Study as the participants of this study, including 855 in preschool and 1,079 in primary school in the 2007 school year, and 990 in junior high schools in the 2008 school year. Table 1 shows the basic information of the students with disabilities, according to which the most prevalent disability category for preschool was developmental delay $(42.9 \%)$, followed by intellectual disabilities $(11.8 \%)$, and language or speech impairments $(8.9 \%)$. The most prevalent disability category for primary school was intellectual disabilities (24.6\%), followed by orthopedic impairments $(15.5 \%)$, and then other health impairments (11.7\%). In the stage of junior high school, the most prevalent disability category was learning disabilities $(25.2 \%)$, followed by orthopedic impairments $(16.2 \%)$, and then intellectual disabilities $(15.2 \%)$.

Table 1

Number of Valid Samples

\begin{tabular}{|c|c|c|c|c|c|c|c|}
\hline \multirow[b]{2}{*}{ Intellectual disabilities } & \multicolumn{2}{|c|}{$\frac{\text { Preschool }}{\mathrm{N} \%}$} & \multicolumn{2}{|c|}{$\frac{\text { Primary school }}{\mathrm{N} \%}$} & \multicolumn{2}{|c|}{$\frac{\text { Junior high school }}{\mathrm{N} \%}$} & \multirow{2}{*}{$\begin{array}{l}\text { Total } \\
516\end{array}$} \\
\hline & 101 & 11.8 & 265 & 24.6 & 150 & 15.2 & \\
\hline Visual impairments & 10 & 1.2 & 28 & 2.6 & 44 & 4.4 & 82 \\
\hline Hearing impairments & 40 & 4.7 & 69 & 6.4 & 61 & 6.2 & 170 \\
\hline Speech or language impairments & 76 & 8.9 & 95 & 8.9 & 19 & 1.9 & 190 \\
\hline Orthopedic impairments & 54 & 6.3 & 168 & 15.5 & 160 & 16.2 & 382 \\
\hline Other health impairments & 38 & 4.5 & 126 & 11.7 & 115 & 11.6 & 279 \\
\hline Emotional and behavior disorders & 19 & 2.2 & 22 & 2.0 & 58 & 5.9 & 99 \\
\hline Learning disabilities & 5 & 0.6 & 55 & 5.1 & 249 & 25.2 & 309 \\
\hline Multiple disabilities & 52 & 6.0 & 51 & 4.7 & 26 & 2.6 & 129 \\
\hline Autism & 69 & 8.0 & 73 & 6.8 & 50 & 5.0 & 192 \\
\hline Developmental delay & 367 & 42.9 & 59 & 5.5 & 0 & 0 & 426 \\
\hline Other significant disabilities & 25 & 2.9 & 67 & 6.2 & 58 & 5.9 & 150 \\
\hline Total & 855 & 100.0 & 1,079 & 100.0 & 990 & 100.0 & 2,924 \\
\hline
\end{tabular}

\section{Materials}

The latent variables, their observed variables, and how they are scored are elaborated as follows:

\section{Teacher Expertise}

(1) Participation of special education workshops in the past year: One to five points were given, respectively, to "zero participation", "less than 18 hours of participation", "18 to 35 hours of participation", "35 to 54 hours of participation", and "54 hours and above". The higher the score, the more hours the teacher has spent on special education workshops.

(2) Were the special education workshops you attended in the past year helpful to the students with disabilities? One to four points are given, respectively, to "not helpful", "not very helpful", "helpful", and "quite helpful". The higher the score, the more the special education workshops are helpful to their teaching.

\section{Human Resources}

(1) What human resources support did you get in the past school year? This is a multiple choice question. One checked choice represents 1 point, while unchecked ones represent 0 points. There are 15 choices under this question for special education teachers, teaching assistants, itinerant teachers, speech and language 
therapists, and nurses. The higher the total score, the more the teacher has received great human resources support.

(2) Do you think itinerant teacher is helpful to you or your students? One to four points are given, respectively, to "not helpful", "not very helpful", "helpful", and "quite helpful".

(3) How well did you cooperate with the special education teachers? One to four points are given, respectively, to "very badly", "badly", "well", and "quite well".

(4) Were relevant professionals (e.g.: physical, occupational, or speech and language therapists) helpful to you? One to four points are given, respectively, to "not helpful", "not very helpful", "helpful", and "quite helpful”.

\section{Teaching Adjustment}

(1) What teaching adjustments did you make for students with disabilities? This is a multiple choice question. One checked choice represents 1 point, while unchecked ones represent 0 points. There are nine choices under this question regarding adjustments in the classroom environment, adjustments in the difficulty and amount of the learning content, and adjustments in teaching strategies and the use of teaching technology. The higher the total score, the more teaching adjustments the teacher has made.

(2) Do you think these adjustments are enough for these students? One to four points are given, respectively, to "far from enough", "not enough", "relatively enough", and "enough".

\section{School Support Services}

(1) What kind of supports did the school provide for teaching this student? This is a multiple choice question. One checked choice represents 1 point, while unchecked ones represent 0 points. There are 9 choices under this question regarding information on the student, scheduling for professional counseling, provision of teaching materials and tools, and provision of extra human resources support. The higher the total score, the more support the school has provided.

(2) What kind of support services did the school provide to this student in the past school year? This is a multiple choice question, where one checked choice represents 1 point. There are 18 choices under this question regarding physical therapy, occupational therapy, speech and language therapy, tuition refunds, scholarships, educational aids, and recording and transcribing services.

(3) What kind of support services did you or the school provide to the parents? This is a multiple choice question. One checked choice represents 1 point, while unchecked ones represent 0 points. There are 6 choices under this question regarding relevant special education, medical information, psychological support, parental education lectures or courses, and help in the application of benefits/allowance.

(4) In your opinion, was the student provided with enough services? One to four points are given, respectively, to "far from enough", "not enough", "relatively enough", and "enough".

\section{Procedure}

This study begins from an analysis of the secondary data drawn from the Special Needs Education Longitudinal Study in Taiwan, works to establish a school support service model for students with disabilities in regular classroom, and probes the different stages of education regarding current school support services for students with disabilities. Model validation is carried out via statistical software package Lisrel 9.1, and frequency distribution and percentage are used as the indicators of how students with disabilities are obtaining support services from school. 


\section{Results}

\section{The School Support Service Model for Students With Disabilities}

The school support service model for preschool. As shown in Figure 2, among the 12 observed variables, only support adequacy has a factor loading as low as 0.29 ; while the loading of the others are all above 0.5 . The composite reliability of the latent variables is between 0.64 and 0.88 , while the average variance extracted is between 0.33 and 0.79 . The results are tested in terms of the overall goodness of fit, according to which $\chi^{2}=299.85$, df $=48$, and $\mathrm{p}<0.001$. However, in further testing of other goodness of fit indicators, GFI, AGFI, NFI, and NNFI are all found to be higher than 0.90 and RMSEA $=0.078$. It is therefore concluded that this model is satisfactory in terms of goodness of fit.

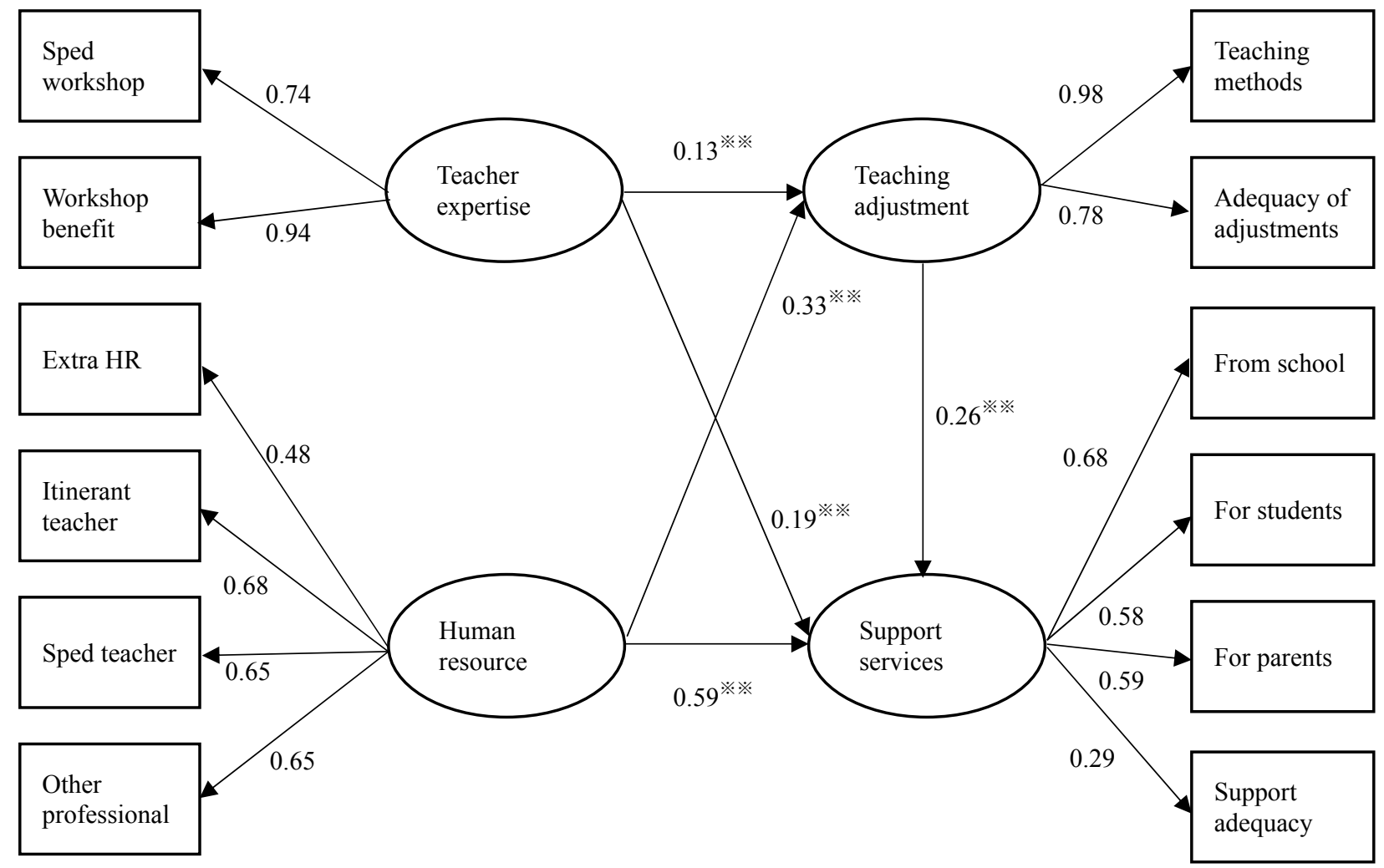

Figure 2. School support service model for preschool.

The school support service model for primary school. According to Figure 3, among the 12 observed variables, only support adequacy has a factor loading as low as 0.32 ; while the loading of the others are all above 0.5 . The composite reliability of the latent variables is between 0.68 and 0.86 , while the average variance extracted is between 0.36 and 0.75 . The results are tested in terms of the overall goodness of fit, according to which $\chi^{2}=406.20, \mathrm{df}=50$, and $\mathrm{p}<0.001$. However, in further testing of other goodness of fit indicators, GFI, AGFI, NFI, and NNFI are all found to be higher than 0.90 and RMSEA $=0.081$. It is therefore concluded that this model is satisfactory in terms of goodness of fit.

School support service model for junior high school. As seen in Figure 4, among the 12 observed variables, only the helpfulness of itinerant teachers, cooperation with special education teachers, and support adequacy have a factor loading lower than 0.5 , which are $0.45,0.49$, and 0.37 , respectively; while the loading 
of the others are all above 0.5 . The composite reliability of the latent variables is between 0.63 and 0.91 , while the average variance extracted is between 0.31 and 0.84 . The results are tested in terms of the overall goodness of fit, according to which $\chi^{2}=308.33, \mathrm{df}=49$, and $\mathrm{p}<.001$. However, in further testing of other goodness of fit indicators, GFI, AGFI, NFI, and NNFI are all found to be higher than 0.90 and RMSEA $=0.073$. It is therefore concluded that this model is satisfactory in terms of goodness of fit.

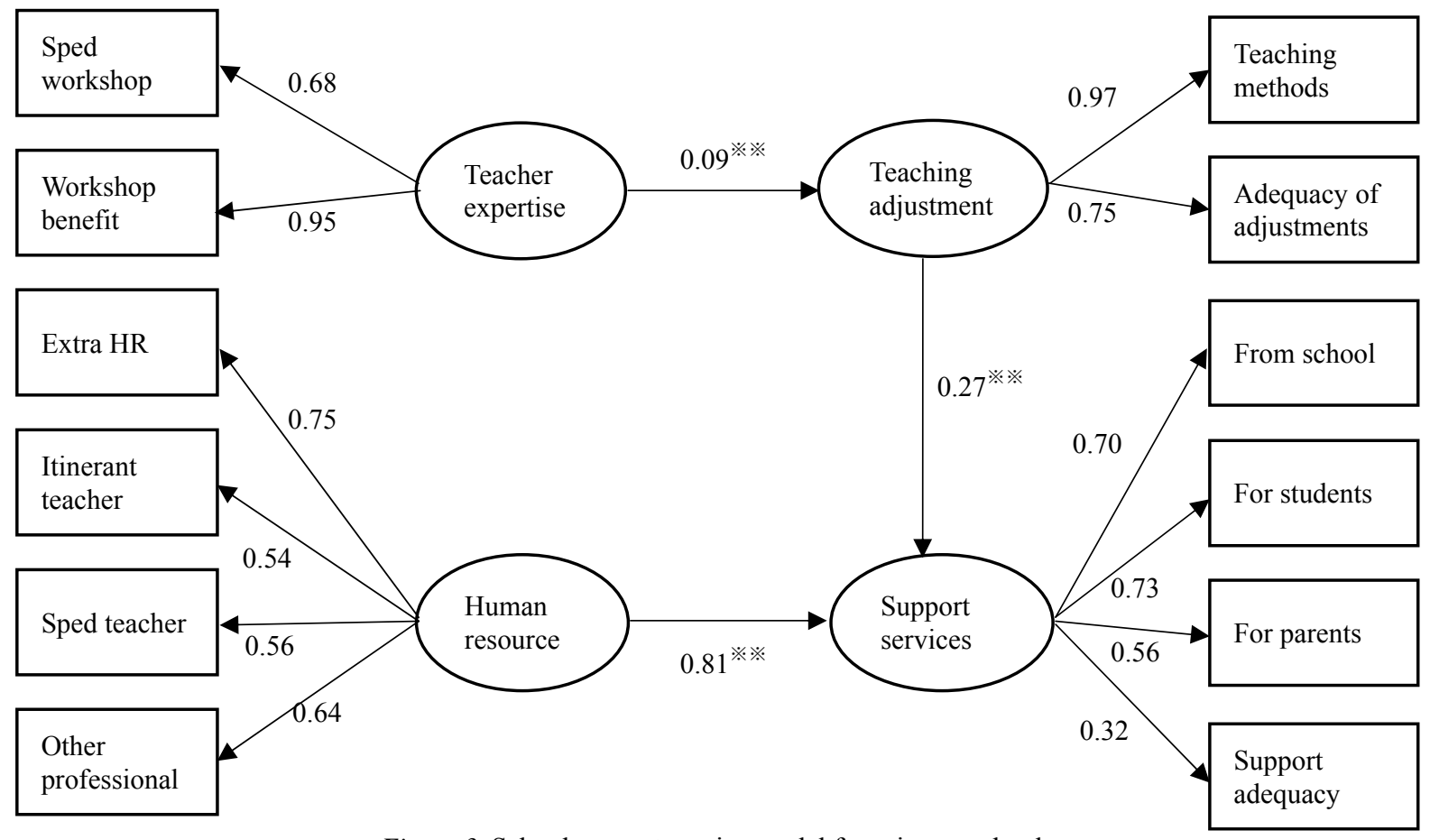

Figure 3. School support service model for primary school.

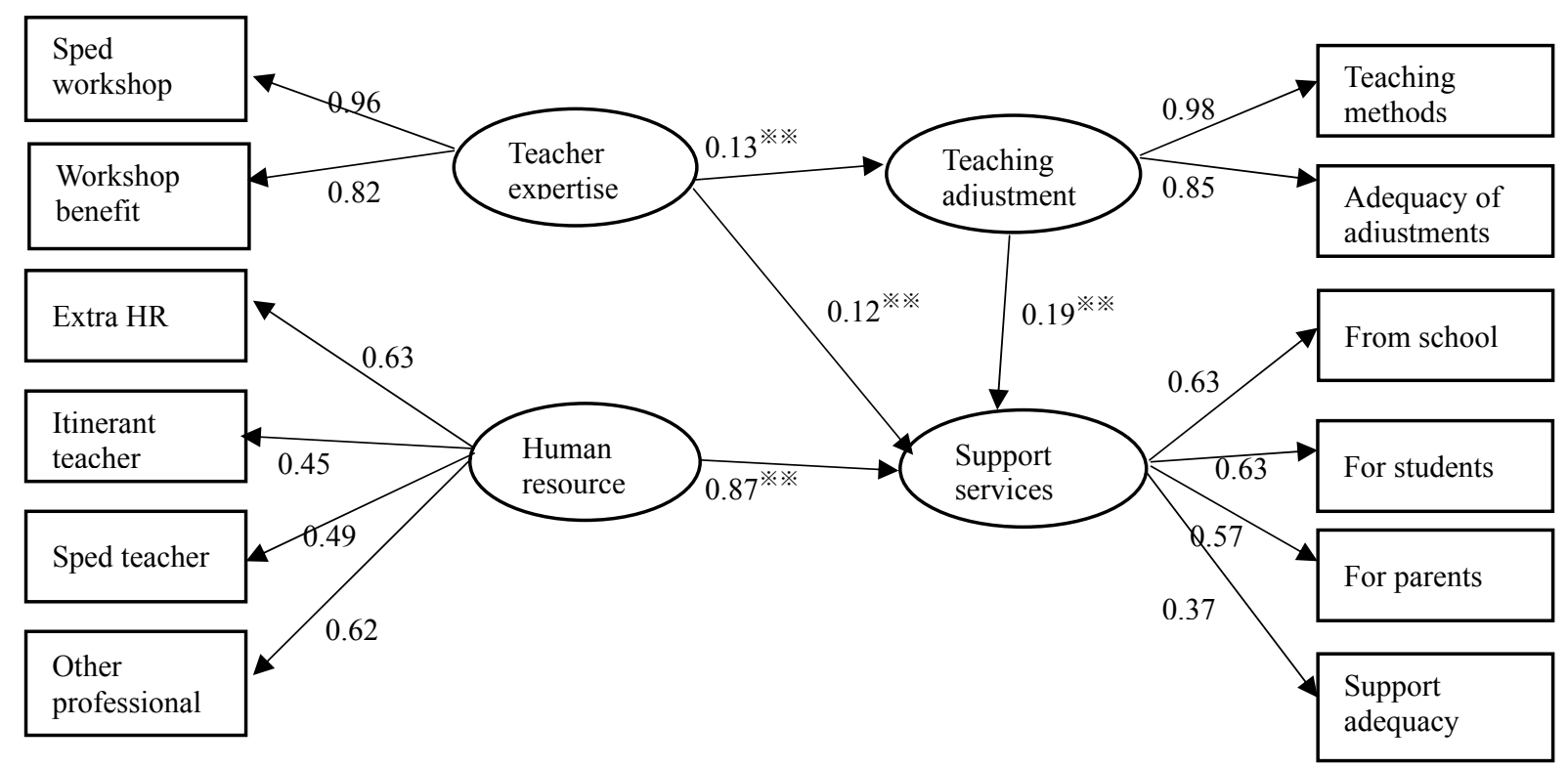

Figure 4. School support service model for junior high school.

In addition, the path coefficients of the school support service models at the three different stages are all found to have reached the significance level of $0.01(t>2.58)$. In terms of the variation of the overall model 
$\left(R^{2}\right)$, as explained by the latent variables, teaching adjustment could explain, respectively, $15 \%, 1 \%$, and $2 \%$ of the overall variation in the three models, while support services could explain, respectively, $63 \%, 75 \%$, and $85 \%$ of the overall variation in the three models. It could be seen from these figures that, teaching adjustment has relatively low explanatory power for the variation of the overall model, while that of support services is satisfactory, peaking at $85 \%$ in the case of the school support service model for junior high school.

\section{The Current Status of School Support Services for Students With Disabilities}

School support services for preschool. According to the results in Table 2, 49.4\% of preschool teachers spent less than 18 hours on special education workshops in the past year, and $65.3 \%$ of the teachers deemed these workshops helpful to their teaching. In terms of human resources, the extra human resources for the class were mostly comprised of itinerant teachers (63.4\%), speech and language therapists (25.5\%), and occupational therapists (19.2\%). In terms of adjustments in teaching, the most common teaching adjustments were adjustments in teaching strategies (52.1\%) and adjustments in classroom environment (51.9\%). It was a less prevalent practice to design extra curriculum for students with disabilities (16.1\%). The most common school support services provided by kindergartens included itinerant services, tuition refunds, speech and language therapy, and occupational therapy. Regarding the support services for parents, the more frequently used methods were providing access to relevant special education information, helping them with applications for benefits/allowance, and giving them psychological support.

School support services for primary school. As seen from the results listed in Table 3, 65.5\% of primary school teachers in regular classes spent less than 18 hours on special education workshops in the past year, and $54.5 \%$ of them deemed these workshops helpful to their teaching. In terms of human resources, the extra human resources were mostly comprised of the parents (31.8), itinerant teachers $(29.1 \%)$, and special education teachers $(25.4 \%)$. In terms of adjustments in teaching, the most common teaching adjustments were adjustments in the classroom environment (47.7\%), adjustments in teaching strategies (34.3\%), and adjustments in the contents, meaning the amount of content or time allowed for the completion of homework (31.1\%). A less prevalent practice was to prepare special teaching materials or tools for students with disabilities (11.7\%). The most common school support services included tuition refunds, itinerant services, adjustments in examinations and assessment, stipends and scholarships, and transportation subsidy. Regarding the support services for parents, the more frequently used methods were providing psychological support, helping them with the application of benefits/allowance, and offering parental education lectures.

School support services for junior high school. As seen from the results listed in Table 4, 54.7\% of junior high school teachers spent less than 18 hours on special education workshops in the past year, and $42 \%$ of them deemed these workshops helpful to their teaching. In terms of human resources, the extra human resources were mostly comprised of special education teachers (46.0\%), counselors (26.0\%), and parents of the students $(21.8 \%)$. In terms of adjustments in teaching, the most common teaching adjustments were adjustments in the classroom environment (20.3\%), adjustments in the content, amount, or time allowed for the completion of homework (15.8\%), and adjustments in teaching strategies (14.4\%). A less prevalent practice was to prepare special teaching materials or tools for students with disabilities (4.1\%). The most common school support services included tuition refunds, stipends and scholarships, psychological counseling or therapy, itinerant services, and adjustments in examinations and assessment. Regarding the support services for parents, the more frequently used methods were providing psychological support, offering parental education lectures, 
giving access to relevant special education information, and helping them with the application of benefits/allowance.

Table 2

Summary of School Support Services for Preschool $(N=855)$

\begin{tabular}{|c|c|c|c|c|}
\hline $\begin{array}{l}\text { Latent } \\
\text { variables }\end{array}$ & Observed variables & Questions & Frequency & Percentage \\
\hline \multirow{8}{*}{$\begin{array}{l}\text { Teacher's } \\
\text { expertise }\end{array}$} & \multirow{4}{*}{$\begin{array}{l}\text { Participation in special } \\
\text { education workshops }\end{array}$} & Less than 18 hours & 423 & 49.4 \\
\hline & & $18 \sim 35$ hours & 122 & 14.3 \\
\hline & & $35 \sim 54$ hours & 38 & 4.5 \\
\hline & & More than 54 hours & 42 & 4.9 \\
\hline & \multirow{4}{*}{$\begin{array}{l}\text { Helpfulness of the special } \\
\text { education workshops }\end{array}$} & Very helpful & 126 & 14.7 \\
\hline & & Helpful & 433 & 50.6 \\
\hline & & Not very helpful & 64 & 7.5 \\
\hline & & Not helpful & 2 & 0.2 \\
\hline \multirow{17}{*}{$\begin{array}{l}\text { Human } \\
\text { resources }\end{array}$} & \multirow{6}{*}{$\begin{array}{l}\text { Extra human resources in the } \\
\text { class }\end{array}$} & Itinerant teachers & 542 & 63.4 \\
\hline & & Speech and language therapists & 218 & 25.5 \\
\hline & & Occupational therapists & 164 & 19.2 \\
\hline & & Parents, family or caregivers of the child & 152 & 17.8 \\
\hline & & Teaching assistants & 120 & 14.1 \\
\hline & & Physical therapists & 93 & 10.8 \\
\hline & \multirow{4}{*}{$\begin{array}{l}\text { Helpfulness of the itinerant } \\
\text { teachers }\end{array}$} & Very helpful & 233 & 27.2 \\
\hline & & Helpful & 301 & 35.2 \\
\hline & & Not very helpful & 75 & 8.7 \\
\hline & & Not helpful & 3 & 0.3 \\
\hline & \multirow{3}{*}{$\begin{array}{l}\text { Cooperation with special } \\
\text { education teachers }\end{array}$} & Very well & 399 & 46.6 \\
\hline & & Fine & 200 & 23.3 \\
\hline & & Not well & 1 & 0.1 \\
\hline & \multirow{4}{*}{$\begin{array}{l}\text { Cooperation with relevant } \\
\text { professionals }\end{array}$} & Very helpful & 219 & 25.6 \\
\hline & & Helpful & 349 & 40.7 \\
\hline & & Not very helpful & 58 & 6.7 \\
\hline & & Not helpful & 2 & 0.2 \\
\hline \multirow{11}{*}{$\begin{array}{l}\text { Adjustment in } \\
\text { teaching }\end{array}$} & \multirow{7}{*}{ Teaching adjustments } & Adjustments in the teaching strategies & 446 & 52.1 \\
\hline & & Adjustments in the classroom environment & 446 & 51.9 \\
\hline & & $\begin{array}{l}\text { Adjustments in the difficulty and amount of the } \\
\text { learning content }\end{array}$ & 377 & 44.1 \\
\hline & & $\begin{array}{l}\text { Adjustments in the content, amount or time } \\
\text { allowed for the completion of homework }\end{array}$ & 307 & 35.8 \\
\hline & & $\begin{array}{l}\text { Preparation of teaching materials and tools to fit } \\
\text { his needs }\end{array}$ & 273 & 32.0 \\
\hline & & $\begin{array}{l}\text { Making use of the assistance from peers, parents } \\
\text { or assistants }\end{array}$ & 236 & 27.6 \\
\hline & & $\begin{array}{l}\text { Designing extra curriculum or activities for him or } \\
\text { her }\end{array}$ & 137 & 16.1 \\
\hline & \multirow{4}{*}{$\begin{array}{l}\text { Adequacy of the adjustment in } \\
\text { teaching }\end{array}$} & Adequate & 124 & 14.5 \\
\hline & & Relatively adequate & 377 & 44.1 \\
\hline & & Inadequate & 87 & 10.1 \\
\hline & & Far from adequate & 4 & 0.4 \\
\hline
\end{tabular}


(table 2 continued)

\begin{tabular}{|c|c|c|c|c|}
\hline $\begin{array}{l}\text { Latent } \\
\text { variables }\end{array}$ & Observed variables & Questions & Frequency & Percentage \\
\hline \multirow{27}{*}{$\begin{array}{l}\text { School } \\
\text { support } \\
\text { services }\end{array}$} & \multirow{9}{*}{ Support for students } & Itinerant services & 568 & 66.4 \\
\hline & & Tuition refunds & 425 & 49.7 \\
\hline & & Speech and language therapy & 409 & 47.9 \\
\hline & & Occupational therapy & 317 & 37.1 \\
\hline & & Teaching assistants or assistants & 232 & 27.1 \\
\hline & & Physical therapy & 171 & 20.0 \\
\hline & & Social work services & 158 & 18.5 \\
\hline & & Transportation subsidy & 121 & 14.2 \\
\hline & & Assistive teaching devices & 120 & 14.0 \\
\hline & \multirow{6}{*}{ Support for parents } & Special education or medical information & 433 & 50.6 \\
\hline & & Application of benefits/allowance & 428 & 50.1 \\
\hline & & Psychological support & 425 & 49.7 \\
\hline & & Professional guidance or counseling & 373 & 43.6 \\
\hline & & Parental education lectures or courses & 363 & 42.4 \\
\hline & & Help with the finding of social resources & 114 & 13.3 \\
\hline & \multirow{8}{*}{$\begin{array}{l}\text { Teaching assistance provided } \\
\text { by the school }\end{array}$} & Professional counseling or itinerant services & 467 & 54.6 \\
\hline & & Special education workshop & 375 & 43.9 \\
\hline & & Provision of student profile & 338 & 39.5 \\
\hline & & Psychological support & 260 & 30.3 \\
\hline & & Arrange case conferences & 190 & 22.2 \\
\hline & & Reduce the size of the class & 154 & 18.0 \\
\hline & & Teaching materials and tools & 164 & 19.2 \\
\hline & & Extra human resources support & 148 & 17.3 \\
\hline & \multirow{4}{*}{$\begin{array}{l}\text { Adequacy of the } \\
\text { services }\end{array}$} & Adequate & 295 & 34.5 \\
\hline & & Relatively adequate & 391 & 45.7 \\
\hline & & Inadequate & 104 & 12.2 \\
\hline & & Far from adequate & 25 & 3.0 \\
\hline
\end{tabular}

Table 3

Summary of School Support Services for Primary School $(N=1079)$

\begin{tabular}{|c|c|c|c|c|}
\hline $\begin{array}{l}\text { Latent } \\
\text { variables }\end{array}$ & Observed variables & Questions & Frequency & Percentage \\
\hline \multirow{8}{*}{$\begin{array}{l}\text { Teacher's } \\
\text { expertise }\end{array}$} & \multirow{4}{*}{$\begin{array}{l}\text { Participation in special } \\
\text { education workshops }\end{array}$} & Less than 18 hours & 707 & 65.5 \\
\hline & & 18 hours to 35 hours & 143 & 13.3 \\
\hline & & 35 hours to 54 hours & 13 & 1.2 \\
\hline & & More than 54 hours & 20 & 1.8 \\
\hline & \multirow{4}{*}{$\begin{array}{l}\text { Helpfulness of the special } \\
\text { education workshops }\end{array}$} & Very helpful & 52 & 4.8 \\
\hline & & Helpful & 536 & 49.7 \\
\hline & & Not very helpful & 267 & 24.8 \\
\hline & & Not helpful & 28 & 2.6 \\
\hline \multirow{6}{*}{$\begin{array}{l}\text { Human } \\
\text { resources }\end{array}$} & \multirow{6}{*}{$\begin{array}{l}\text { Extra human resources in the } \\
\text { class }\end{array}$} & Parents, family or caregivers of the student & 343 & 31.8 \\
\hline & & Itinerant teachers & 314 & 29.1 \\
\hline & & special education teachers & 274 & 25.4 \\
\hline & & Speech and language therapists & 105 & 9.8 \\
\hline & & Nurses & 102 & 9.4 \\
\hline & & Occupational therapists & 100 & 9.3 \\
\hline
\end{tabular}


(table 3 continued)

\begin{tabular}{|c|c|c|c|c|}
\hline $\begin{array}{l}\text { Latent } \\
\text { variables }\end{array}$ & Observed variables & Questions & Frequency & Percentage \\
\hline \multirow{11}{*}{$\begin{array}{l}\text { Human } \\
\text { resources }\end{array}$} & \multirow{4}{*}{$\begin{array}{l}\text { Helpfulness of the itinerant } \\
\text { teachers }\end{array}$} & Very helpful & 158 & 14.6 \\
\hline & & Helpful & 192 & 17.8 \\
\hline & & Not very helpful & 55 & 5.1 \\
\hline & & Not helpful & 6 & 0.5 \\
\hline & \multirow{3}{*}{$\begin{array}{l}\text { Cooperation with special } \\
\text { education teachers }\end{array}$} & Very well & 394 & 36.5 \\
\hline & & Fine & 237 & 22.0 \\
\hline & & Not well & 3 & 0.3 \\
\hline & \multirow{4}{*}{$\begin{array}{l}\text { Cooperation with } \\
\text { professionals }\end{array}$} & Very helpful & 93 & 8.6 \\
\hline & & Helpful & 275 & 25.5 \\
\hline & & Not very helpful & 81 & 7.5 \\
\hline & & Not helpful & 10 & 1.0 \\
\hline \multirow{11}{*}{$\begin{array}{l}\text { Adjustment } \\
\text { in teaching }\end{array}$} & \multirow{7}{*}{ Teaching adjustments } & Adjustments in the classroom environment & 514 & 47.7 \\
\hline & & Adjustments in the teaching strategies & 370 & 34.3 \\
\hline & & $\begin{array}{l}\text { Adjustments in the content, amount or time } \\
\text { allowed for the completion of homework }\end{array}$ & 335 & 31.1 \\
\hline & & Adjustment in the means of assessment & 305 & 28.2 \\
\hline & & $\begin{array}{l}\text { Making use of the assistance from peers, parents } \\
\text { or assistants }\end{array}$ & 271 & 25.1 \\
\hline & & $\begin{array}{l}\text { Adjustments in the difficulty and amount of the } \\
\text { learning content }\end{array}$ & 270 & 25.1 \\
\hline & & $\begin{array}{l}\text { Preparation of teaching materials and tools to fit } \\
\text { his needs }\end{array}$ & 127 & 11.7 \\
\hline & \multirow{4}{*}{$\begin{array}{l}\text { Adequacy of the adjustment in } \\
\text { teaching }\end{array}$} & Adequate & 137 & 12.7 \\
\hline & & Relatively adequate & 348 & 32.2 \\
\hline & & Inadequate & 128 & 11.9 \\
\hline & & Far from adequate & 19 & 1.8 \\
\hline \multirow{25}{*}{$\begin{array}{l}\text { School } \\
\text { support } \\
\text { services }\end{array}$} & \multirow{9}{*}{ Support for students } & Tuition refunds & 438 & 40.6 \\
\hline & & Itinerant services & 356 & 33.0 \\
\hline & & Adjustments in examinations & 330 & 30.6 \\
\hline & & Stipends and scholarships & 264 & 24.5 \\
\hline & & Transportation subsidy & 254 & 23.5 \\
\hline & & Speech and language therapy & 152 & 14.1 \\
\hline & & Assistive teaching devices & 146 & 13.5 \\
\hline & & Accessible environments and facilities & 136 & 12.6 \\
\hline & & Occupational therapy & 119 & 11.0 \\
\hline & \multirow{6}{*}{ Support for parents } & Psychological support & 528 & 49.0 \\
\hline & & Application of benefits/allowance & 412 & 38.2 \\
\hline & & Parental education lectures or courses & 408 & 37.8 \\
\hline & & Relevant special education or medical information & 347 & 32.2 \\
\hline & & Professional guidance or counseling & 295 & 27.3 \\
\hline & & Help with the finding of social resources & 98 & 9.0 \\
\hline & \multirow{6}{*}{$\begin{array}{l}\text { Teaching assistance provided } \\
\text { by the school }\end{array}$} & Provision of student profile & 389 & 36.1 \\
\hline & & Professional counseling or itinerant services & 358 & 33.2 \\
\hline & & Reduce the size of the class & 317 & 29.3 \\
\hline & & Psychological support & 267 & 24.7 \\
\hline & & Arrange case conferences & 289 & 26.8 \\
\hline & & Special education workshops & 255 & 23.6 \\
\hline & \multirow{4}{*}{$\begin{array}{l}\text { Adequacy of the } \\
\text { services }\end{array}$} & Adequate & 340 & 31.5 \\
\hline & & Relatively adequate & 442 & 41.0 \\
\hline & & Inadequate & 180 & 16.6 \\
\hline & & Far from adequate & 37 & 3.4 \\
\hline
\end{tabular}


Table 4

Summary of School Support Services for Junior High School $(N=990)$

\begin{tabular}{|c|c|c|c|c|}
\hline $\begin{array}{l}\text { Latent } \\
\text { variables }\end{array}$ & Observed variables & Questions & Frequency & Percentage \\
\hline \multirow{8}{*}{$\begin{array}{l}\text { Teacher's } \\
\text { expertise }\end{array}$} & \multirow{4}{*}{$\begin{array}{l}\text { Participation in special } \\
\text { education workshops }\end{array}$} & Less than 18 hours & 542 & 54.7 \\
\hline & & 18 hours to 35 hours & 45 & 4.5 \\
\hline & & 35 hours to 54 hours & 9 & 0.9 \\
\hline & & More than 54 hours & 14 & 1.4 \\
\hline & \multirow{4}{*}{$\begin{array}{l}\text { Helpfulness of the special } \\
\text { education workshops }\end{array}$} & Very helpful & 32 & 3.3 \\
\hline & & Helpful & 383 & 38.7 \\
\hline & & Not very helpful & 178 & 18.0 \\
\hline & & Not helpful & 16 & 1.6 \\
\hline \multirow{17}{*}{$\begin{array}{l}\text { Human } \\
\text { resources }\end{array}$} & \multirow{5}{*}{$\begin{array}{l}\text { Extra human resources in the } \\
\text { class }\end{array}$} & Special education teachers & 455 & 46.0 \\
\hline & & Counselor & 258 & 26.0 \\
\hline & & Parents, family or caregivers of the student & 216 & 21.8 \\
\hline & & Itinerant teachers & 150 & 15.2 \\
\hline & & Nurses & 106 & 10.7 \\
\hline & \multirow{4}{*}{$\begin{array}{l}\text { Helpfulness of the itinerant } \\
\text { teachers }\end{array}$} & Very helpful & 44 & 4.4 \\
\hline & & Helpful & 164 & 16.5 \\
\hline & & Not very helpful & 29 & 2.9 \\
\hline & & Not helpful & 1 & 0.1 \\
\hline & \multirow{4}{*}{$\begin{array}{l}\text { Cooperation with special } \\
\text { education teachers }\end{array}$} & Very well & 414 & 41.8 \\
\hline & & Fine & 317 & 32.0 \\
\hline & & Not well & 10 & 1.0 \\
\hline & & Badly & 1 & 0.1 \\
\hline & \multirow{4}{*}{$\begin{array}{l}\text { Cooperation with relevant } \\
\text { professionals }\end{array}$} & Very helpful & 109 & 11.0 \\
\hline & & Helpful & 237 & 23.9 \\
\hline & & Not very helpful & 67 & 6.8 \\
\hline & & Not helpful & 22 & 2.2 \\
\hline \multirow{12}{*}{$\begin{array}{l}\text { Adjustment } \\
\text { in teaching }\end{array}$} & \multirow{8}{*}{ Teaching adjustments } & Adjustments in the classroom environment & 201 & 20.3 \\
\hline & & $\begin{array}{l}\text { Adjustments in the content, amount or time } \\
\text { allowed for the completion of homework }\end{array}$ & 157 & 15.8 \\
\hline & & Adjustments in the teaching strategies & 142 & 14.4 \\
\hline & & $\begin{array}{l}\text { Adjustments in the difficulty and amount of the } \\
\text { learning content }\end{array}$ & 118 & 11.9 \\
\hline & & Adjustments in the means of assessment & 107 & 10.8 \\
\hline & & $\begin{array}{l}\text { Make use of the assistance from peers, parents or } \\
\text { assistants }\end{array}$ & 106 & 10.7 \\
\hline & & $\begin{array}{l}\text { Design extra curriculum or activities for him or } \\
\text { her }\end{array}$ & 52 & 5.2 \\
\hline & & $\begin{array}{l}\text { Preparation of teaching materials and tools to fit } \\
\text { his needs }\end{array}$ & 40 & 4.1 \\
\hline & \multirow{4}{*}{$\begin{array}{l}\text { Adequacy of the adjustment in } \\
\text { teaching }\end{array}$} & Adequate & 44 & 4.4 \\
\hline & & Relatively adequate & 186 & 18.8 \\
\hline & & Inadequate & 61 & 6.2 \\
\hline & & Far from adequate & 12 & 1.2 \\
\hline
\end{tabular}


(table 4 continued)

\begin{tabular}{|c|c|c|c|c|}
\hline $\begin{array}{l}\text { Latent } \\
\text { variables }\end{array}$ & Observed variables & Questions & Frequency & Percentage \\
\hline \multirow{25}{*}{$\begin{array}{l}\text { School } \\
\text { support } \\
\text { services }\end{array}$} & \multirow{8}{*}{ Support for students } & Tuition refunds & 341 & 34.5 \\
\hline & & Stipends and scholarships & 236 & 23.8 \\
\hline & & Psychological counseling or therapy & 229 & 23.1 \\
\hline & & Itinerant services & 223 & 22.6 \\
\hline & & Adjustments in examinations & 194 & 19.6 \\
\hline & & Transportation subsidy & 136 & 13.8 \\
\hline & & Teaching assistants or assistants & 113 & 11.4 \\
\hline & & Accessible environments and facilities & 103 & 10.4 \\
\hline & \multirow{6}{*}{ Support for parents } & Psychological support & 546 & 55.2 \\
\hline & & Parental education lectures or courses & 435 & 43.9 \\
\hline & & $\begin{array}{l}\text { Relevant special education, medical or } \\
\text { employment information }\end{array}$ & 326 & 32.9 \\
\hline & & Application of benefits/allowance & 313 & 31.6 \\
\hline & & Professional guidance or counseling & 274 & 27.7 \\
\hline & & Help with the finding of social resources & 88 & 8.9 \\
\hline & \multirow{7}{*}{$\begin{array}{l}\text { Teaching assistance provided } \\
\text { by the school }\end{array}$} & Provision of student profile & 622 & 62.8 \\
\hline & & Psychological support & 372 & 37.6 \\
\hline & & Arrange case conferences & 367 & 37.0 \\
\hline & & Professional counseling or itinerant services & 354 & 35.8 \\
\hline & & Reduce the size of the class & 319 & 32.2 \\
\hline & & Special education workshops & 229 & 23.1 \\
\hline & & Extra human resources support & 111 & 11.2 \\
\hline & \multirow{4}{*}{$\begin{array}{l}\text { Adequacy of the support } \\
\text { services }\end{array}$} & Adequate & 284 & 28.7 \\
\hline & & Relatively adequate & 418 & 42.2 \\
\hline & & Inadequate & 147 & 14.8 \\
\hline & & Far from adequate & 24 & 2.5 \\
\hline
\end{tabular}

\section{Discussion}

Based on the results, the highest proportion of teachers who have spent over 35 hours on special education workshops is seen among preschool teachers, and the greater proportion of these teachers deemed the special education workshops as helpful. In terms of human resources, the most prevalent category is itinerant teachers, followed by speech and language therapists and parents. At the stage of primary school, the most prevalent categories are itinerant teachers and school-based special education teachers. In junior high schools, the most prevalent categories are school-based special education teachers, counselors, and parents. Since resource room and special education classes are already part of the school settings of primary and junior high schools in Taiwan, the support provided by school-based special education teachers is actually greater than that provided by itinerant teachers. However, parents are important human resources support in all the three stages of education.

In terms of adjustments in teaching, classroom environments, teaching strategies, and the contents or time allowed for the completion of homework are the most frequently used methods in different stages of education. However, rarely are efforts made to design curriculums or teaching materials and tools that fit the needs of students with disabilities. Although O'Rourke and Houghton (2008) found that adjustments in curriculum, homework, and support from teachers were effective in helping students with mild disabilities to 
enhance their learning outcomes, Carlson, Bitterman, and Daley (2010) showed that as many as $44 \%$ of preschool teachers were not making any changes or adjustments to their curriculum for children with special needs. Dowrick, Anderson, Heyer, and Acosta (2005) also indicated that regular classroom teachers had low intentions to adjust their curriculum or teaching materials in response to the needs of students with disabilities.

In terms of school support services for students with disabilities, the most prevalent services provided in preschools are itinerant services, tuition refunds, speech and language therapy, and occupational therapy. In primary schools, the more common support services are tuition refunds, itinerant services, adjustments in examinations and assessment, and stipends and scholarships. In junior high schools, tuition refunds, stipends and scholarships, psychological counseling, and itinerant services are more often seen. As resource rooms are not available in preschools, they tend to attach more importance to early intervention, itinerant services, speech and language therapy, and occupational therapy, which account for the highest proportion of all their support services. In primary and junior high schools, itinerant services are provided at a lower frequency, while support services, such as tuition refunds, stipends and scholarships, psychological counseling, and adjustments in examinations and assessment account for the higher proportion. These results support Tagayuna et al. (2005), who found that the more frequently provided school support services were adjustments in examinations, individual counseling, etc. However, these research findings differ from that reported by NLTS2, who highlighted that the most prevalent support services for secondary school students with disabilities were speech and language therapy, occupational therapy or vocational rehabilitation, transcription, and mobility services (U.S. Department of Education, 2004).

\section{Conclusion}

In summation, this study establishes a school support service model for students with disabilities in preschools, primary, and junior high schools. In this study, though the path coefficients of the school support service models at the three different stages are different, they all reached a significance level of 0.01 . In addition, the support services show a satisfactory explanation of the variation of the overall model, peaking in the case of the school support service model for junior high school at $85 \%$. Moreover, this study found that, while itinerant teachers constitute an important human resource for preschools; in primary and junior high school-based special education teachers and parents play this role. Regular classroom teachers rely most frequently on adjustments to classroom environments, teaching strategies, and the content or time allowed for the completion of homework. The most prevalent services provided in preschools are itinerant services, tuition refunds, speech and language therapy, and occupational therapy. In primary and junior high schools, stipends and scholarships, psychological counseling, and adjustments in examinations and means of assessment are more often used.

The results of this study show that regular classroom teachers in primary and junior high school tend to spend less time on special education workshops, which might create a difference in their professional competencies when teaching students with disabilities, as well as their use of teaching adjustments. It is therefore suggested that education authorities should adopt regular classroom teachers taking a more active part in special education workshops, in order to better teach students with disabilities. 


\section{References}

Academia Sinica. (2014). Special needs education longitudinal study. Taipei City: Survey Research Data Archive of Academia Sinica.

Alquraini, T., \& Gut, D. (2012). Critical components of successful inclusion of students with severe disabilities: Literature review. International Journal of Special Education, 27(1), 42-59.

Blackorby, J., Korkey, A., Wagner, M., Levine, P., Schiller, E., \& Sumi, C. (2007). What makes a difference? Influences on outcomes for students with disabilities. Menlo Park, CA: Office of Special Education Programs, U.S. Department of Education.

Carlson, E., Bitterman, A., \& Daley, T. (2010). Access to educational and community activities for young children with disabilities. Rockville, MD: Westat. Retrieved from http://www.peels.org

Coffey, K. M., \& Obringer, S. J. (2004). A case study on Autism: School accommodations and inclusive settings. Education, 124(4), 632-639.

Cook, B. G. (2001). A comparison of teachers' attitudes toward their included students with mild and severe disabilities. The Journal of Special Education, 34, 203-214.

Cook, B. G. (2004). Inclusive teachers' attitudes toward their students with disabilities: A replication and extension. The Elementary School Journal, 104, 307-321.

Downing, J. E., \& Peckham-Hardin, K. (2007). Supporting inclusive education for students with severe disabilities in rural areas. Rural Special Education Quarterly, 26(2), 10-15.

Dowrick, P. W., Anderson, J., Heyer, K., \& Acosta, J. (2005). Postsecondary education across the USA: Experiences of adults with disabilities. Journal of Vocational Rehabilitation, 22, 41-47.

Forlin, C. (1995). Educators' beliefs about inclusive practices in Western Australia. British Journal of Special Education, 22, 179-185.

Jindal-Snape, D., Douglas, W., Topping, K. J., Kerr, C., \& Smith, E. F. (2005). Effective education for children with autistic spectrum disorder: Perceptions of parents and professionals. The International Journal of Special Education, 20(1), 77-87.

Koenig, K. P., Bleiweiss, J., Brennan, S., Cohen, S., \& Siegel, D. E. (2009). The ASD nest program-A model for inclusive public education for students with autism spectrum disorders. Teaching Exceptional Children, 42(1), 6-13.

Maheady, L., Mallette, B., \& Harper, G. E. (2006). Four classwide peer toturing models: Similarities, differences, implications for research and practices. Reading and Writing Quarterly, 22, 65-89.

Mastropieri, M. A., Scruggs, T. E., Graetz, J., Norland, J., Gardizi, W., \& McDuffie, K. (2005). Case studies in co-teaching in the content areas: Successes, failures, and challenges. Intervention in School and Clinic, 40, 260-270.

O'Rourke, J., \& Houghton, S. (2008). Perceptions of secondary school students with mild disabilities to the academic and social support mechanisms implemented in regular classrooms. International Journal of Disability, Development and Education, 55(3), 227-237.

Santoli, S. P., Sachs, J., Romey, E. A., \& McClurg, S. (2008). A successful formula for middle school inclusion: Collaboration, time, and administrative support. Research in Middle Level Education, 32(2), 1-13.

Tagayuna, A., Stodden, R. A., Chang, C., Zeleznik, M. E., \& Whelley, T. A. (2005). A two-year comparison of support provision for persons with disabilities in postsecondary education. Journal of Vocational Rehabilitation, 22, 13-21.

U.S. Department of Education. (1999). Assistance to the states for the education of children with disabilities. Retrieved from http//www.ideapractices.org/law/index.php

U.S. Department of Education. (2004). Services and supports for secondary school students with disabilities: A special topic report of findings from the national longitudinal transition study-2 (NLTS2). Menlo Park, CA: Office of Special Education Programs, U. S. Department of Education.

U.S. Department of Education. (2014). 34th Annual Report to Congress on the Implementation of the Individuals with Disabilities Education Act, 2012. Washington, D.C.: U.S. Department of Education.

Varma, C. (2007). Improving quality of elementary education by monitoring professional competencies of teachers for inclusive education. ED 494892.

Vaughn, S., \& Schumm, J. S. (1995). Responsible inclusion for students with learning disabilities. Journal of Learning Disabilities, 28, 264-270. 